\title{
Toxicity Test on Wedusan (Ageratum spp.) Extract Against Sitophilus spp. (Coleoptera: Curculionidae)
}

\begin{abstract}
Tropical condition in Southeast Asia has contributed around 30\% of post harvest damage as it provide optimum condition for the growth of Sitophilus spp. pest. Therefore, this study was aimed to investigate the effect of wedusan extract on controlling Sitophilus spp. Growth. Wedusan extract was given in different level of concentrations. The research used the Randomized Complete Design. Wedusan (Ageratum spp.) extract affected the imago mortality of Sitophilus spp. There were two kinds of Wedusan extract used in this study, dried extract (DE) and fresh extract (FE). Sitophilus imago were put into bottles filled with organic rice and were treated with Wedusan extract. The mortality level was obsered at 24 Hours After Application (HAA), $48 \mathrm{HAA}$, and $72 \mathrm{HAA}$. The highest toxicity was found by the treatment of dried extract of wedusan 5 tablets, by LC50 55\% on 24 HAA and $82.25 \%$ on 72 HAA. Extract of dry matter has higher toxicity effect than fresh extract. The application of wedusan extract is eviromental friendly and specific-range against pest. It is promising for future development as natural product in agriculture area.
\end{abstract}

Keywords: Sitophilus spp., Ageratum spp., toxicity, storehouse pest

\section{INTRODUCTION}

The quality and quantity of food and seed storages have become frequently reduced. One of the causes is the infestation of storehouse pest (Sitophilus spp). Tropical climate and moist condition at Southeast Asia have damaged post harvest, which is estimated to reach 30\% [1]. Storehouse pest controls have been done chemically, physically, and biologically. However, the chemical control is the most requently used since the other more effective control methods have not been found yet [2]. Despite of the drawbacks that chemical pesticide bring, it still become the superior in controlling the storehouse pests [3].

The increasing serious problems, such as resistance, pesticide residue, and biosphere contamination as the effects of synthetic pesticide application in large-scale has encouraged various research on diverse materials including floral materials as the alternative insecticide to control pest [4]. Floral insecticide has some superiorities,

${ }^{*}$ Corresponding author:

Erinus Mosip

Faculty of Agriculture, Brawijaya University

Jalan Veteran, Malang, Indonesia 65145

E-mail: leksimosip@yahoo.co.id such as environmentally safe, short spectrum, easily degradable, safe residue for the stored products, and easily obtained [5].

The vegetation biodiversity in Indonesia has various potential of active materials that can also be used as the source of floral insecticides [6]. Wedusan (Ageratum spp.) is one of vegetations that is easily found at almost the whole areas in Indonesia, which is belongs to asteraceae family [7]. Wedusan contains some active compounds, such as saponin, flavanoid, polyphenol, and ageratochmone that have been known as toxic substances to insects [8]. It has been reported that these compounds may cause death on Sitophilus spp., inhibit insects growth, and may cause some defects. The application of Wedusan powder on Sitophilus spp. may increase its mortality and affect on its population. Wedusan chemical properties have been also reported in eliminating and controlling Sitophilus spp. pest as it is environmentally safe and harmless for human health [9]. Furthermore, it

\section{How to cite:}

Mosip E, Raharjo BT, Astuti LP (2018) Toxicity Test on

Wedusan (Ageratum spp.) Extract Against Mortality of Sitophilus spp. (Coleoptera: Curculionidae). J. Trop. Life. Science 8 (1): 11 -15 . 
is required to conduct study about the toxicity test of Wedusan extract against Sitophilus spp. in order to investigate the effectiveness of Wedusan as floral insecticide [10].

\section{MATERIALS AND METHODS}

\section{Research design and sample preparation}

The research design was Randomized Complete Design (RCD) by two factors and six treatments (four replications). Sitophilus spp. was collected from rice for the poors to be put into new contained filled with $0.5 \mathrm{~kg}$ and placed in a room at $\pm 29^{\circ} \mathrm{C}$ on average and average humidity $\pm 75 \%$. Rearing procedures of Sitophilus spp. was performed is modified from established method by International Rice Research Institute (IRRI) [11]. Three hundred grams of Wedusan extract was homogenized with $50 \mathrm{ml}$ Tween 80 and $300 \mathrm{ml}$ aquadest. The homogenized extract was then mixed with $300 \mathrm{~g}$ rice flour and stirred well until form pasta. Furthermore, the pasta was mold into tablet.

A total $5 \mathrm{~kg}$ of organic rice was previously kept at cold temperature for 24 hours in order to avoid any infestation of pests and other pathogens. Rice were ten divided into 250 bottles using analytic scale or 20 gram rice for each bottle (height: $9 \mathrm{~cm}$, diameter: $5 \mathrm{~cm}$ ). Each bottle was labeled according to the treatment. The imago were then infested approximately at the same age, which each bottle containing 20 Sitophilus spp. imago.

\section{Toxicity test on Wedusan extract}

The mortality of insects was observed following the treatment at 24 hours, 48 hours, and 72 hours after application (HAA). The percentage of insects' mortality could be a good indicator for insecticidal activity [12]. Mortality percentage of Sitophilus spp. was counted using the equation below:

$$
\text { Mortality }=\frac{\text { Died Sitophilus spp. } \quad \times 100 \%}{\text { Tested Sitophillus spp. }}
$$

If death was found on the control (not more than 20\%), then death percentage should be corrected by equation [13] as follow:

\section{Note:}

$$
p=\frac{(x-y)}{x} \times 100 \%
$$

$\mathrm{p}$ is the percentage of the corrected death

$\mathrm{x}$ is the percentage of the life of the control

$\mathrm{y}$ is a percentage of the living pest at the treatment
$\mathrm{LC}_{50}$ was calculated using probit analysis program (probit value $50 \%$ ) or manually using the obtained regression equation. The relationship between extract's concentration and mortality level of insects was analyzed through regression analysis. The obtained probit regression determined the value of $\mathrm{LC}_{50}$ (the optimum dose of extract to eliminate $50 \%$ of the insect population). It can be calculated using the equation [14] below:

$$
y=b x+a
$$

Note:

$\mathrm{y}$ is concentration $\log$

$\mathrm{x}$ is probit number

\section{Data analysis}

Data was analyzed using analysis of variance (ANOVA) wit significant level of 0.05. If any difference between treatments was found on the results, it may be followed by further test using Least Significant Difference (LSD) of $5 \%$.

\section{RESULTS AND DISCUSSION}

The mortality level of insects (Table 1 ) shows that Wedusan extract treatment against Sitophilus spp. at 24 hours after application are signiicantly difference at different concentrations. Treatment by DEy5 (dry extract of the concentration of 5 tablets) contributed the highest mortality level of Sitophilus spp. at all observation times. However, the lowest mortality level was obtained from the control groups of DEy0 and FEy0. Furthermore, DE (dry extract of Wedusan) performs better in inducing the mortality of Sitophilus spp. than FE (fresh extract of Wedusan).

In a closer look, the effect of DE y4 (4 tablets) in inducing mortality of Sitophilus spp. is better than of DE y3 (3 tablets). Moreover, DE y3 performance is better than DE y2 (2 tablets). In the other words, the higher concentration of wedusan extract was given the higher mortality level of Sitophilus spp. Likewise, te fresh material of Wedusan at concentration of FE y4 (4 tablets) performs better in inducing the mortality of Sitophilus spp. than FE y3 (3 tablets).

In average, the mortality level of insects induced by dry extract was higher than induced by fresh extract. It is expected caused by the active materials contained in dry extract are more concentrated than in fresh extract due to low water content. On the other hand, fresh extract has more water content and less rendement in the form of fine extract. Therefore, in order to obtain an 
Table 1. Average mortality of Sitophilus spp.

\begin{tabular}{|c|c|c|c|c|c|c|c|c|c|c|c|c|}
\hline \multirow{4}{*}{ Concentration Level } & \multicolumn{12}{|c|}{ Types of Extract } \\
\hline & \multicolumn{6}{|c|}{ DE (dry extract) } & \multicolumn{6}{|c|}{ FE (fresh extract) } \\
\hline & \multicolumn{6}{|c|}{ Hours after application (HAA) } & \multicolumn{6}{|c|}{ Hours after application (HAA) } \\
\hline & \multicolumn{2}{|c|}{24} & \multicolumn{2}{|c|}{48} & \multicolumn{2}{|c|}{72} & \multicolumn{2}{|c|}{24} & \multicolumn{2}{|c|}{48} & \multicolumn{2}{|c|}{72} \\
\hline y0 & 0.71 & $\mathrm{~d}$ & 0.71 & $\mathrm{~d}$ & 0.71 & $\mathrm{e}$ & 0.71 & $\mathrm{e}$ & 0.71 & e & 0.71 & e \\
\hline $\mathrm{y} 1$ & 1.76 & c & 2.21 & c & 2.39 & $\mathrm{~d}$ & 1.48 & $\mathrm{~d}$ & 2.06 & $\mathrm{~d}$ & 2.73 & $\mathrm{~d}$ \\
\hline $\mathrm{y}^{2}$ & 2.05 & c & 2.49 & $b$ & 2.87 & c & 1.86 & $\mathrm{c}$ & 2.45 & c & 2.91 & $\mathrm{~cd}$ \\
\hline y3 & 2.39 & $\mathrm{~b}$ & 2.64 & $b$ & 3.81 & $\mathrm{~b}$ & 2.12 & bc & 2.45 & c & 3.81 & c \\
\hline $\mathrm{y} 4$ & 3.12 & a & 3.9 & $\mathrm{a}$ & 4.15 & $\mathrm{a}$ & 2.34 & $\mathrm{~b}$ & 2.78 & b & 3.31 & $\mathrm{~b}$ \\
\hline y5 & 3.39 & a & 4.12 & a & 4.21 & $\mathrm{a}$ & 3.08 & $\mathrm{a}$ & 3.39 & a & 3.37 & $\mathrm{a}$ \\
\hline LSD 5\% & & & & & & & 28 & & & & & \\
\hline
\end{tabular}

Note :- Average numbers followed by the same letter in the same column show insignificant differences on level test of 5\%, HAA

= Hours After Application, $\mathrm{DE}=$ dry extract, $\mathrm{FE}=$ fresh extract.

- Different alphabets indicate significant differences between treatment.

insecticidal extract, it should be aerated dry first to reduce water content [15].

Overall, there were some differences found between the lowest and the highest concentrations (1 tablet and 5 tablets of Wedusan extracts) respectively, which leads to different effect of mortality. The higher concentration of of Wedusan extracts induce the higher mortality of Sitophilus spp. imago. As it was presumed that such response was caused by more and stronger chemical compounds of Wedusan, which become toxic to Sitophilus spp.

Insects with low survival ability died more quickly within 24 hours after application (HAA) or less than 24 HAA. Meanwhile, the resistant insects might die within 48 and 72 HAA. The insect's death and its adaptation towards extract treatment are the natural mechanisms as self-defence from the environmental stress.

Mortality on Sitophilus spp. was presumed to be the effect of activity of floral insecticide compounds in of Wedusan extract. Those active compounds including coumarin, flavonoid, alkaloid, saponin, triterpenoid, phenol, and ageratochmone. It was presumed that Wedusan extract entered into insects' body through respiratory organs. As the result, imago died immediately following the treatment [16].

Insecticide that enter into the insect's body through respiratory tract as a result of fumigation will be distributed and accumulated, which furtherly form lethal toxin for the insects. Besides, it was presumed that the pest's death was caused by toxic compound in Wedusan extra- ct that entered into insect's body through digestive tract [17].

Wedusan contains coumarine compounds, which can interrupt the electron transport in respiration process. Coumarin plays role as inhibitor in electron transport process on mitochondria and reduce ATP production. Therefore, it may result in muscular disturbance due to the lack of energy, which is required for cellular activities. This would make the insects die. Surangin $\mathrm{B}$ is one of Coumarin molecule compounds. Another research has reported activities of these compounds group to affect other insect species as well. It has been reported that these compounds are considered as antifeedant and growth inhibitor for insects, and they may disturb the hormonal mechanism. Surangin B is a protein inhibitor of electron in mitochondria transport trough in vitro tha can be toxic for insects [18].

The flavonoid contain in Wedusan has catecholic ring $-\mathrm{B}$, which can be toxic against the insects [19]. In this context, there is a correlation between Rotenone antimycin A, and hydramethylnone as floral insecticides in which all of those chemical elements have blocked the electron transport in insects' transpiration process [20]. In addition, coumarin and furanocoumarins may change the detoxification ability of an organism, which reversibly and irreversibly inhibits cytochrome detoxification enzyme.

After all, Wedusan is potentially can be utilized as the substitute of synthetic insecticide. The extract is packed in tablets that works slowly by releasing aromatic 
Table 2. Result of analysis $\mathrm{LT}_{50}$

\begin{tabular}{|c|c|c|c|c|}
\hline \multirow{2}{*}{$\begin{array}{c}\text { Concentration } \\
\text { (Tablet) }\end{array}$} & \multicolumn{2}{|c|}{ Dry Extract } & \multicolumn{2}{|c|}{ Fresh Extract } \\
\hline & Equation & $\mathrm{LT}_{50}$ & Equation & $\mathrm{LT}_{50}$ \\
\hline y1 (4.4) & $y=2.590+0.967 x$ & 310.82 & $y=0.775+2.041 x$ & 117.56 \\
\hline y2 (8.8) & $y=2.377+1.247 x$ & 126.72 & $y=1.690+1.635 x$ & 105.80 \\
\hline y3 (13.1) & $y=2.927+1.017 x$ & 108.97 & $y=2.096+1.452 x$ & 99.92 \\
\hline y4 (17.5) & $y=1.773+2.278 x$ & 26.12 & $y=2.206+1.509 x$ & 70.98 \\
\hline y5 (21.9) & $y=2.209+2.140 x$ & 20.15 & $y=3.504+0.984 x$ & 33.16 \\
\hline
\end{tabular}

Table 3. Result of analysis $\mathrm{LC}_{50}$

\begin{tabular}{ccccc}
\hline \multirow{2}{*}{$\begin{array}{c}\text { Time } \\
\text { (Hour) }\end{array}$} & \multicolumn{2}{c}{ Dry Extract } & \multicolumn{2}{c}{ Fresh Extract } \\
\cline { 2 - 5 } & $\mathrm{y}=2.525+1.850 \mathrm{x}$ & 21.757 & $\mathrm{y}=2.434+1.661 \mathrm{x}$ & 35.062 \\
24 & $\mathrm{y}=2.365+2.429 \mathrm{x}$ & 12.157 & $\mathrm{y}=3.205+1.260 \mathrm{x}$ & 26.56 \\
48 & $\mathrm{y}=2.528+2.496 \mathrm{x}$ & 9.7744 & $\mathrm{y}=3.901+0.972 \mathrm{x}$ & 13.491 \\
72 & & &
\end{tabular}

Note: $\mathrm{LC}_{50}=$ Lethal concentration

gas in a closed room. It can be used as as fumigant tablet. Fumigation using wedusan extract could induce mortality of insects [21]. Toxicity test using $\mathrm{LC}_{50}$ method is an acute toxicity test method, in which the toxic effect of compounds could be determined in a short time following the application of tested concentration [21].

$\mathrm{LC}_{50}$ values are the required concentrations to eliminate $50 \%$ of the tested insects. $\mathrm{LC}_{50}$ values in Table 2 reduced along with the longer duration of observation. The longer duration of the observation, the higher mortality percentage of the insects.

In order to accelerate the toxicity reaction on the insects to higher concentration of Wedusan extract is required to eliminate $50 \%$ of the insects for 24 hours. If the concentration was reduced, it might take longer time to eliminate $50 \%$ of the insects as the insecticide may react systemically.

Data of the research showed that the lower concentration of the floral insecticide extract needs the longer time to eliminate $50 \%$ of the insects. It is presumed due to less toxin contained in the low concentration of insecticide that reduces the effectivity of extract to induce insect mortality. If the chemical reaction is slow, it may take longer to eliminate $50 \%$ insects, while under the higher concentration of insecticide it may take the relatively shorter time. Furtermore, $\mathrm{LC}_{50}$ values reduced along with the observation duration, in which the longer the observation time, the higher level mortality of Sitophilus spp. will be observed [22].

\section{CONCLUSION}

Wedusan (Ageratum spp.) extract affects against mortality of Sitophilus spp. imago. The highest toxicity level was found by the application of 5 tablets of dry wedusan extract treatment, by the value of $\mathrm{LC}_{50} 55 \%$ at $24 \mathrm{HAA}$ and $82.25 \%$ at 72 HAA. Dry extract showed higher toxicity effect than fresh extract.

\section{ACKNOWLEDGMENT}

The authors would like to thank to Department of Plant Pathology, Faculty of Agriculture, Brawijaya University for supporting this research.

\section{REFERENCES}

1. Abbot WS (1925) A method of computing the effectiveness of an insecticide. Journal of Economic Entomology 18 (2): 265 - 267. doi: 10.1093/jee/18.2.265a.

2. Kwesi A, Surajit KDD (1991) A handbook for weed control in rice. Manila, International Rice Research Institute.

3. Bakkali F, Averbeck S, Averbeck D, Idaomar M (2008) Biological effects of essential oils-A review. Food and Chemical Toxicology 46 (2): 446 - 475. doi: 10.1016/j.fct. 2007.09.106.

4. Finney DJ (1971) Probit analysis Third Edition. Cambridge, Cambridge University Press.

5. Fitriani A (2014) Alkaloid activity of Ageratum conyzoides 
L. against the growth of bacterial Staphylococcus aureus in vitro. In Proceeding Symposium on Research of Natural Therapeutic Material (SPBOA) XVI dan Muktamar XII PERHIPBA: 23 - 24 April 2014

6. Gani S (2010) Uji efektivitas tepung daun Babadotan (Ageratum conyzoides L.) terhadap kumbang beras (Sitophilus oryzae L.) (Coleoptera: Curculionidae) di laboratorium. Jurnal Manggaro 11: $33-35$.

7. Chi H (1997) Computer program for probit analysis. Taichung, National Chung Hsing University.

8. Molide R, Agus K, Tri LM et al. (2010) Pemanfaatan 6 jenis pestisida nabati untuk menurunkan serangan hama simplisia dan Sitophilus oryzae (50\%). http://balittro.litbang.pertanian.go.id/. Accessed: October 2017.

9. Ming LC (1999) Ageratum Conicoid's: A tropical source of medicinal and agricultural product. In: Janick, ed. Perspectives on new crops and new uses. Alexandria, ASHS Press. pp $469-473$.

10. Moreira MD, Picanco MC, Barbosa LCA et al. (2007) Plant compounds insecticide activity against Coleoptera pests of stored products. Pesquisa Agropecuária Brasileira 42 (7): 909 - 915. doi: 10.1590/S0100-204X2007000700001.

11. Heinrichs EA, Rapusas HR (1985) Genetic evaluation for insect resistance in rice. Virginia, Agribookstore.

12. Devi KC, Devi SS (2013) Insecticidal and oviposition deterrent properties of some spices against coleopteran beetle, Sitophilus oryzae. Journal of Food Science and Technology 50 (3): $600-604$.

13. Nicholson RA, Zhang AG (1995) Surangin B: Insecticidal properties and mechanism underlying its transmitter releasing action in nerve terminal fractions isolated from mammalian brain. Pesticide Biochemistry and Physiology 53 (3): 152 - 163. doi: 10.1006/pest.1995.1063.

14. Onyilagha JC, Lazorko J, Gruber MY et al. (2004) Effect of flavonoids on feeding preference and development of the crucifer pest. Journal of Chemical Ecology 30 (1): 109 - 124. doi: 10.1023/B:JOEC.0000013185.62475.65.

15. Dadang, Prijono D (2008) Insektisida nabati: Prinsip, pemanfaatan, dan pengembangan (floral insecticide, utilization and development). Bogor, Department of Plant Protection - Agricultural Institute of Bogor.

16. Mannetje L, Jones RM (eds.) (1992) Plant resources of South-East Asia No. 4 Forages. Wageningen, Pudoc.

17. Rees D (2004) Insects of stored products. Victoria, CSIRO Publishing.

18. Setiawan D (2010) Kajian daya insektisida ekstrak daun mimba (Azadirachta indica A. Juss) terhadap perkembangan serangga hama gudang Sitophilus oryzae Linn. Jurnal Penelitian Sains $10: 6-12$.

19. Surtikanti (2004) Kumbang bubuk Sitophilus zeamais Motsch. (Coleoptera: Curculionidae) dan strategi pengendaliannya. Jurnal Litbang Pertanian 23 (4): 123 129.

20. Suryaningsih E, Hadisoeganda WW (2004) Pestisida botani untuk mengendalikan hama dan penyakit pada tanaman sayuran. Bandung, Balai Penelitian Tanaman Sayuran.

21. Usman LA, Zubair MF, Olawore NO et al. (2013) Chemical constituents of flower essential oil of Ageratum conyzoides growing in Nigeria. Organic Chemistry 54 (2013): 12463 12465.

22. Utami S, Haneda NF (2010) Pemanfaatan etnobotani dari hutan tropis Bengkulu sebagai pestisida. Jurnal Manajemen Hutan Tropical 16 (3): 143 - 147. 